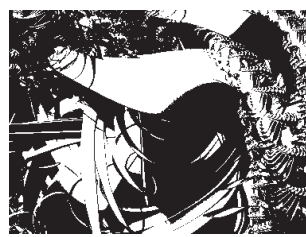

doi:10.5559/di.20.1.08

\title{
AN ANALYSIS OF \\ SEX RATIO AT BIRTH \\ IN CROATIA 1946 - 2007
}

Dario PAVIĆ

Centre for Croatian Studies, Zagreb

UDK: $314.35(497.5)^{\prime \prime} 1946 / 2007^{\prime \prime}$

Izvorni znanstveni rad

Primljeno: 17. 4. 2009.

Sex ratio at birth has been one of the most studied, yet most poorly understood demographic phenomena. Numerous physiological, ecological and demographic factors seem to influence it although an unequivocal explanation is lacking. Indeed, some countries have exhibited a trend in the sex ratio at birth over the years. Their sex ratio at birth time-series can be modeled with the non-random stochastic processes which reflect the interdependency in the subsequent annual observations. This article examines sex ratio at birth for the Republic of Croatia during the years 1946 to 2007 . The tests for assessing the time-series were performed, along with the autoregression modeling. The Croatian time-series is the product of a pure random process with no observable time trend despite the presence of some factors known to affect the sex ratio at birth. It is suggested that the size of the live-birth population is not great enough to reflect the subtle changes in these factors.

Keywords: sex ratio at birth, Croatia, time series analysis, autoregression

$\triangle \quad$ Dario Pavić, Department of Sociology, Centre for Croatian Studies, University of Zagreb, Borongajska cesta 83d, 10000 Zagreb, Croatia.

E-mail: dpavic@hrstud.hr

\section{INTRODUCTION}

Sex ratio at birth is defined as the ratio of male live-births to female live-births. In most human populations this ratio is relatively constant and its value averages around 1.07, which indicates an excess of male live-births (107 male births for every 100 female births), although there are countries that exhibit at 
DRUŠ. ISTRAŽ. ZAGREB GOD. 20 (2011), BR. 1 (1 111$)$,

STR. 151-165

PAVIĆ, D.:

AN ANALYSIS OF SEX.. least some departure from this value (Mathews and Hamilton, 2005; Parazzini et al., 1998). The proportion of male births is the ratio of male live-births to total number of live-births ( $\mathrm{u}$ sually around 0.515 ), and is used as a measure of sex ratio at birth in this study. Both of these measures tend to become equal during the reproductive age due to a higher male mortality (Teitelbaum, 1971).

However, systematic deviations from this ratio were observed in conditions such as war (Graffelman and Hoekstra, 2000; James, 2003a, 2004a; Polasek et al., 2005; Saadat and Ansari-Lari, 2004; Zorn et al., 2002), natural and economic catastrophes (Catalano, 2003; Fukuda et al., 1998), chronic stress (Saadat and Ansari-Lari, 2004) etc. It has been observed that certain demographic categories of people exhibited different patterns of sex ratio at birth even in the absence of catastrophic events or chronic stress, which in turn led to the investigation of factors affecting sex ratio at birth. The demographic factors associated with sex ratio at birth are ethnicity (Mathews and Hamilton, 2005), mother's age (James, 1971a, 2001a), father's age (Jacobsen, 2001; Nicolich et al., 2000), birth order (Jacobsen et al., 1999), mother's weight (Cagnacci et al., 2004), smoking (Mills et al., 2003), certain professions (James, 2005a), exposure to pollutants (James, 2003a, 2005a; Vartiainen et al., 1999), seasonality of births (James, 1971b), certain pathological conditions (James, 2006, 2007) etc. It has been shown by these studies that older parental age, higher birth order (third and every subsequent child), extremely low or high mother's weight, exposure to pollutants and short-termed stress raise the probability of bearing a female child, thus lowering the sex ratio at birth.

The impact of the exogenous factors on sex ratio at birth is mediated through hormonal mechanisms at conception or during gestation (James, 1987). Certain conditions associated with different types and levels of sex hormones affect differential conception by sex. These conditions are a natural variation of sex hormones (James, 2004b; Gray et al., 1998; Grant, 1996), length of the follicular phase of the cycle (Martin, 1997), time of insemination (Gray et al., 1998), coital frequency (James, 1997), non-optimal maturation of oocytes (Jongbloet, 2004; James, 2004c), pathological states (James, 2001b; Crawford et al., 1987) and nutritional status at conception (Mathews et al., 2008). Furthermore, the sex ratio at birth can be a function of differential survival during embryogenesis (Boklage, 2005). Apart from these proximate determinants of sex ratio at birth, an ultimate evolutionary explanation has been proposed by Trivers and Willard (1973). They have argued that natural selec- 
DRUŠ. ISTRAŽ. ZAGREB GOD. 20 (2011), BR. 1 (111),

STR. 151-165

PAVIĆ, D.

AN ANALYSIS OF SEX.. tion has favored the individuals with the ability to vary the sex ratio at birth, depending on the severity of external conditions. Although well corroborated on animal populations their hypothesis still lacks support when tested on human populations (Gaulin and Robbins, 1991).

Along with the research on factors associated with the sex ratio at birth, the investigations of longitudinal data for certain countries were undertaken. The characteristics of the sex ratio at birth time-series were first described by Gini (1955, cited in James, 2000) who found that sex ratio at birth moves in a non-random manner across time, implying some sort of homeostatic control (James, 1995). In addition, research by Graffelman and Hoekstra (2000), states that the common model for the sex ratio data for most European countries is an integrated moving average model (ARIMA $(0,1,1)$ ), which implies the dependence between successive sex ratio observations. It is hypothesized that similar factors affect the sex ratio at birth and that these factors change only gradually across time. It should be noted that all these investigations were conducted on large populations with a high annual number of live-births.

Other investigators focused on long-term changes and trends in sex ratio, especially during the second half of the twentieth century (Ulizzi and Zonta, 1994, 1995; Mathews and Hamilton, 2005; Lee Davis et al., 2007; Parazzini et al., 1998; Allan et al., 1997; Marcus et al., 1998). The studies showed a decrease in sex ratio at birth in Northern and Eastern European countries, North America and Mexico, and an increase in sex ratio at birth in Mediterranean countries. However, some countries' sex ratio at birth remained stable over time. There is no clear explanation for this data and it is assumed that causes of these trends may be multifactorial.

Sex ratio at birth is one of the most important demographic phenomena with a direct impact on fertility. Higher sex ratio at birth, especially if preserved to the reproductive age, lowers the net reproduction rate and the rate of reproductive growth, just as it lengthens the population's doubling-time (Teitelbaum, 1972). Despite its general importance, the analysis of the sex ratio at birth, to my knowledge, has never been done systematically for the Croatian data. It was briefly mentioned by Pokos (2007), but without an application of any statistical tests. Polasek et al. (2005) and Polasek (2006) analyzed data for the Croatian Homeland War period (1991-1995), as well as for the other ex-Yugoslav countries, trying to establish the relationship between war and sex ratio. They found no significant change in sex ratio at birth during wartime in Croatia, at both the country and county levels. 
DRUŠ. ISTRAŽ. ZAGREB GOD. 20 (2011),

BR. $1(111)$,

STR. 151-165

PAVIĆ, D.:

AN ANALYSIS OF SEX...
The aim of this article is to analyze the data on sex ratio at birth for the Republic of Croatia from 1946 to 2007 by using a time series analysis. This will reveal the type of stochastic process which describes the series, since it has shown that for the large populations this process is non-random. Also, this study will show whether a trend exists in sex ratio at birth, as previously recorded for numerous countries across the world.

\section{MATERIALS AND METHODS}

For purposes of the following analysis, data on sex ratio at birth was collected from the vital statistics reports issued by the Central Bureau of Statistics of the Republic of Croatia for years 1946 to 2007. The Republic of Croatia has only existed as an independent country since 1990 and was formerly known as the Socialist Republic of Croatia, which was established in 1945, and was a constituent part of the Socialist Federal Republic of Yugoslavia. However, the borders of today's Republic of Croatia remain the same as those of the Socialist Republic of Croatia, so this data can be used without any additional manipulation. During the Homeland War, from 1991 to 1995, the authorities of the Republic of Croatia did not control the entire territory of the country, part of which was occupied by the rebellious Serbian forces. At this time, more than ten percent of the Croatian population were refugees (Živić, 1999), so the data from these years is surely not representative, but is the only available. Also, the immigration in Croatia from the neighboring belligerent countries during wartime affected the usability of the data (Gelo, 1999).

The data was ordered in the time-series, and standard tests for evaluation of the time series were performed. The procedure for the univariate time-series analysis, defined by Cromwell et al. (1994), was followed. The first thing provided were the descriptive statistics. To assess the stationarity of the series - i.e. whether it possesses a constant mean, and whether it needs differencing in order to establish which stochastic process produced the series - the augmented Dickey-Fuller (ADF) test was performed. The normality of distribution of data was tested by the Shapiro-Wilk test. A Ljung-Box test was performed to evaluate the independence of the series, i.e. to establish whether the underlying process is random or not. In addition, an autoregression was performed, thereby regressing the sex ratio data over time variable to evaluate the possibility of a trend in the series. Only one predictor (TIME) was used to assess whether the time alone could account for the possible regularity and trend in the data. In the regression analysis Yule-Walker estimates were used. 
$\rightarrow$ FIGURE 1

Graph of the sex ratio at birth and total number of live-births for the Republic of Croatia for the years 1946-2007. $\rightarrow$ TABLE 1

Results for the time-series tests of the Croatian sex ratio at birth data for the years 1946-2007
The total number of live-births in Croatia during the 1946 to 2007 period is 4,034,144, from which 2,078,319 are male live-births and 1,955,825 are female live-births. One should note that from the late 1940s there is a pronounced decline in the total number of live-births, with some fluctuations, ranging from 96,407 live-births in 1949 to an average of 41,000 live-births in mid 2000s (Figure 1).

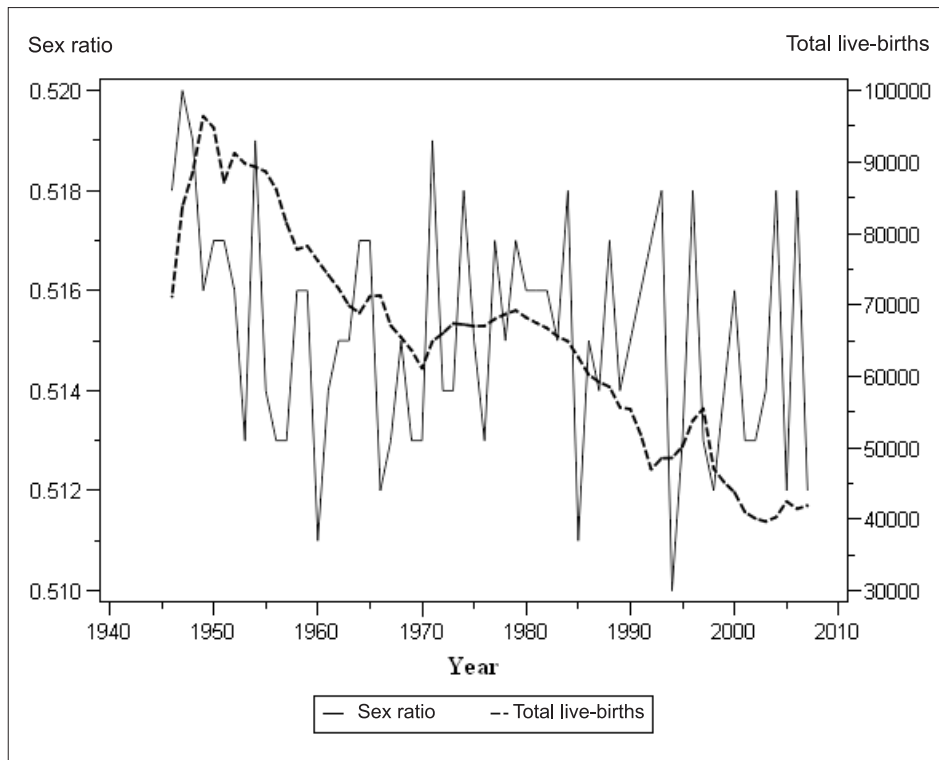

As for the sex ratio at birth data for the Republic of Croatia for the years 1946 to 2007 (also shown in Figure 1), the mean of the series is 0.515067 with a standard deviation of 0.0022698 (binomial distribution). The highest sex ratio is in the year 1947 (0.52), while the lowest is in 1994 (0.51). These ratios have z-scores of 2.222 and -2.67 respectively, which are both significant at $\mathrm{p}=0.05$ level.

\begin{tabular}{|c|c|c|c|}
\hline & Test performed & & \\
\hline \multirow[t]{4}{*}{ Stationarity test } & Augmented & & \\
\hline & Dickey-Fuller test & Tau & $\operatorname{Pr}<$ Tau \\
\hline & Single mean & -7.96 & 0.0001 \\
\hline & Trend & -8.27 & $<.0001$ \\
\hline \multirow[t]{3}{*}{ Independence test } & Ljung-Box test & Q & p-value \\
\hline & Lag 1 & 0.1955 & 0.6583 \\
\hline & Lag 2 & 0.2142 & 0.8984 \\
\hline \multirow[t]{2}{*}{ Normality test } & Shapiro-Wilk test & W & $\operatorname{Pr}<W$ \\
\hline & & 0.987037 & 0.7578 \\
\hline
\end{tabular}


DRUŠ. ISTRAŽ. ZAGREB GOD. 20 (2011) BR. $1(111)$

STR. 151-165

AN ANALYSIS OF SEX...

(1) TABLE 2

Results for the autoregression analysis of the Croatian sex ratio years 1946-2007
PAVIĆ, D.: at birth data for the

The results of the time-series tests are shown in Table 1. The results of the ADF test suggest that the series is stationary and needs no differencing in order to evaluate the series model. It also implies that the series exhibits a constant mean and variance over time and a lack of any type of deterministic trend. The Ljung-Box test shows that the series is independent, with no autocorrelation for lags 1 and 2 . The values and residuals of the series are normally distributed, as suggested by the result of the Shapiro-Wilk test. All these results indicate that the time-series for sex ratio at birth in Croatia from 1946 to 2007 is a result of a pure random process centered around the mean of 0.515 . This series can be expressed with the equation model:

$\mathrm{Y}(\mathrm{t})=0.515+\mathrm{e}(\mathrm{t})$,

where $\mathrm{e}(\mathrm{t})$ is random, normally distributed error term.

Autoregression

\begin{tabular}{lllllc}
\hline Variable & DF & Estimate & Standard Error & t value & App. Pr $>$ t \\
Intercept & 1 & 0.5734 & 0.0294 & 19.52 & $<.0001$ \\
Time & 1 & -0.000029 & 0.0000149 & -1.98 & 0.0521 \\
Total R-square & 0.062 & & & & \\
Durbin-Watson & 1.9919 & & & & \\
\hline
\end{tabular}

The results of the linear regression model for the variable sex ratio at birth over time, shown in Table 2, indicate that the time (variable TIME) is not a statistically significant predictor of sex ratio at birth. The Durbin-Watson test implies no autocorrelation in the data. These results additionally confirm that the series is the product of a random process with no observable trend.

\section{DISCUSSION AND CONCLUSION}

The mean value of the sex ratio at birth in Croatia from 1946 to 2007 is similar to the mean value of other countries, especially the European ones (Parazzini et al., 1998). There are two values that significantly differ from this mean, namely sex ratio for the years 1947 and 1994. It is a well documented fact that after the Second World War there has been an increase in the sex ratio at birth (Graffelman and Hoekstra, 2000), so the value for year 1947 could be the reflection of the post-war effect on sex ratio at birth. However, given the number of observations, this result can also be due to a chance.

The sex ratio at birth for the year 1994, although significantly different from the mean, cannot be considered as a proof for the existence of the genuine effect. Based on the z-scores and the significance level of $p=0.05$, in order to be significant, 
DRUŠ. ISTRAŽ. ZAGREB GOD. 20 (2011), BR. $1(111)$

STR. 151-165

PAVIĆ, D.:

AN ANALYSIS OF SEX.. the sex ratio value has to differ from the mean of 0.515 at least 0.0044 in either direction. The total number of live-births for a single year has to be at least 79,000 in order for the test to detect the difference of that magnitude, given the significance level of 0.05 and power of 0.8 . Since the total number of live-births in 1994 is 48,584 , the significant value of the sex ratio at birth for that year cannot be the reflection of the genuine effect. For that matter, every number of live-births after 1959 is not big enough to detect the effect if it really exists.

The shown robustness and the randomness of the sex ratio at birth in Croatia over the studied period seem like remarkable features, since more than a dozen factors affecting the sex ratio at birth have been identified. Unfortunately, the significant change in factors mentioned by the investigators, analyzing the sex ratio at birth in other countries, is not present in the Croatian data. The most important of these factors is the birth order which was often invoked as the best predictor of the sex ratio at birth, with higher birth order resulting in a lower sex ratio at birth (Ruder, 1985; Mathews and Hamilton, 2005; Ulizzi and Zonta, 1995). For example, at least from 1968 onwards, the data on birth order obtained from Croatian Central Bureau of Statistics show no significant change in birth order in Croatia, especially in the category of first-borns. If the birth order is indeed the major predictor of the sex ratio at birth, this could explain the lack of a trend in the Croatian data.

What strikes one the most is the robustness of the sex ratio at birth over time in relation to some of the proposed predictors of the sex ratio at birth, which themselves did change in Croatia during the past sixty years. The mean age of a mother for her first birth increased from 22.6 years in 1971 to 25.7 years in 2001 and the still-birth rate slightly decreased over the studied period. However, there was no observable effect on sex ratio at birth.

Even more puzzling are the possible societal and economic explanations of the changing sex ratio. During the studied period, the Croatian social picture underwent a change from the post Second World War crisis to the establishment of the communist social and economic system (which lasted forty five years, not itself without perturbations), and finally to the Homeland War period and the establishment of the independent state with a market-oriented economy. The sixty years studied were characterized by the rapid industrialization, urbanization and significant improvements in health care and education. These circumstances produced demographic effects, commonly named the demographic transition, which included lower mortality and fertility (Total fertility rate 2.9 in 1950, 1.67 in 1996), fewer children per woman (3.3 children in 1950s, 
DRUŠ. ISTRAŽ. ZAGREB GOD. 20 (2011),

BR. $1(111)$

STR. 151-165

PAVIĆ, D.:

AN ANALYSIS OF SEX..
1.96 children in 1991) and a higher life expectancy ( 59.05 years for men and 63.2 years for women in 1953, 71.1 years for men and 78.1 years for women in 2001) (Mrđen and Friganović, 1998).

Also due to mostly economic reasons the emigration of Croatian population was pronounced, especially during the 1960s and 1970s, but also after that period. It is estimated that by 1991 there were 286,088 emigrants from Croatia, reaching the number of 415,386 in 1998 (Gelo 1999). Furthermore, the live-births from the emigrant population were often reported as occurring in Croatia, and the percentages of those falsely reported live-births were 7.2, 3.3 and 7.9 for the periods 1971-1981, 1981-1991 and 1991-1997 respectively (Akrap, 1999).

The Croatian Homeland War period brought additional population changes in Croatia. Apart from the Croatian refugee population, there has been a significant Serbian emigration from the Republic of Croatia, and the number of those people was 280,230 in 1998 (Gelo, 1999). The refugee population from Bosnia and Herzegovina was significant for years 1992-1996, averaging around 200,000 people. However, most of these people (Muslims and Croats) did not stay for a long period of time in Croatia. Nevertheless, 150,000 people from Bosnia and Herzegovina and Federal Republic of Yugoslavia (mostly Croats) found their residence in Croatia (data for 1998, Gelo, 1999). Despite all of these social, economic and migration changes, sex ratio at birth remained constant and unaffected for the studied period.

As already mentioned, some reports suggest that the sex ratio at birth can be affected by the exogenous pollutants and pesticides, smoking, some congenital diseases, and profession of the parents or their life habits. It is difficult to assess whether these factors had an impact on the Croatian population due to a lack of reliable data and research. It has also been suggested that these factors could not have affected the whole population, and the prospective research should compare the sex ratio of the affected subpopulations with the control group.

The results of this preliminary study indicate that the sex ratio - when it comes to the Croatian population from 1946 to 2007 - is most likely a robust measure, unaffected by the environment and other exogenous shocks. Furthermore, they show, along with other research (Maconchie and Roman, 1997), that the variations in the sex ratio at birth are completely due to chance. Although much has been written about physiological mechanisms as the causes of deviation from the usual sex ratio at birth, it seems that these mechanisms cannot produce a significantly altered sex ratio at birth at the population level, especially if the size of the population is not of great magnitude. In line with this reasoning, there have been warnings that 
DRUŠ. ISTRAŽ. ZAGREB GOD. 20 (2011), BR. 1 (111)

STR. 151-165

PAVIĆ, D.

AN ANALYSIS OF SEX.. changes in sex ratio at birth are subtle and that large populations are needed for the tests to be powerful enough to record these changes (James, 1987).

When it comes to the Republic of Croatia, the annual number of births never exceeded 90,000 during the studied period, so it seems that the magnitude of the population is indeed the prerequisite for the factors affecting the sex ratio at birth to drive the series in a specific direction. As it has been shown above, the number of live-births for the most part of the Croatian data is not big enough for the test to detect a significant and meaningful change in sex ratio at birth. When the population size and the number of births are not of great magnitude, one should expect a complete randomness in the series. This finding is of great importance since it can identify the populations that are unlikely to exhibit this trend or some sort of dependence in the sex ratio at birth data.

However, this does not mean that the investigation of sex ratio at birth on small populations per se is superfluous. The phenomenon of sex ratio at birth can be investigated on a smaller population but different methodology has to be utilized. Indeed, small-scale research on the effect of the different environmental pressures on the sex ratio at birth have been undertaken with success, as already mentioned. Also, the clinical studies of sex ratio at birth are by definition very restricted in the number of participants. All of these studies yielded their results by the use of regression analysis or non-parametrical statistical tests.

In this report, to say that the population is not great enough means that this type of long-term time-series analysis requires bigger population, so the relevant factors which have a small, but important effect on sex ratio at birth can be discernable in the time-series model. If this is not the case, we argue that the series will exhibit the randomness.

Some of the shortcomings of this study have already been mentioned in the discussion of the results, most notably the insufficient number of live-births for each year. Also, this study aimed to give a general overview of the sex ratio changes in Croatia, but failed to pinpoint the exact factors and mechanisms involved in sex ratio adjustment at population level.

One limitation of this article is the number of years considered for the time-series analysis. While appropriate from the statistical and methodological point, it can be argued that the sixty-two-year period is not long enough to reflect all the changes, seasonal variations and random shocks that can help in elucidating the long term pattern of the sex ratio at birth. The problem exists, however, with the availability of the historical data and the endeavor of acquiring those data would go far beyond this type of study. 
DRUŠ. ISTRAŽ. ZAGREB GOD. 20 (2011), BR. $1(111)$

STR. 151-165

PAVIĆ, D.: AN ANALYSIS OF SEX..

\section{REFERENCES}

It can be argued that the linear regression model which failed to reach significance, is generally not the best model for assessing the Croatian sex ratio at birth data, since it accounted only for $6 \%$ of the variance. The higher order polynomial functions could explain more variance, thus providing a better understanding of the process in place. While it is certainly true that the higher order polynomials (namely the quartic function) and even the spline functions can explain more variance than the simple linear model, the interpretation of the trend in the data in this case becomes very difficult if not impossible. The choice of the linear model was a trade-off between the amount of variance explained and the easily observable potential trend, the latter being the focus of this article.

The prospective study of the sex ratio at birth in Croatia will assess the predictors of sex ratio at birth at the population level by regression analysis, and if these predictors turn out to be significant, to then evaluate whether their magnitude is big enough to change the sex ratio at birth in the future. Also, it will focus on the Croatian subpopulations with respect to their regional, economic and demographic characteristics in order to establish whether there exist different patterns of sex ratio at birth. Furthermore, the next step in the research will be the time-series analysis of the data for countries with a similar annual number of births as Croatia's, in order to establish whether the randomness of the sex ratio at birth is a universal feature.

Allan, B. B., Brant, R., Seidel, J. E. \& Jarrell, J. F. (1997), Declining Sex Ratios in Canada. CMAJ Canadian Medical Association Journal, 156 (1): 37-41.

Akrap, A. (1999), Vitalna statistika i različitost depopulacijskih procesa u Hrvatskoj i županijama. Društvena istraživanja, 8 (5-6): 793-815.

Boklage, C. E. (2005), The Epigenetic Environment: Secondary Sex Ratio Depends on Differential Survival in Embryogenesis. Human Reproduction, 20 (3): 583-587.

Cagnacci, A., Renzi, A., Arangino, S., Alessandrini, C. \& Volpe, A. (2004), Influences of Maternal Weight on the Secondary Sex Ratio of Human Offspring. Human Reproduction, 19 (2): 442-444.

Catalano, R. A. (2003), Sex Ratios in the Two Germanies: A Test of the Economic Stress Hypothesis. Human Reproduction, 18 (9): 1972-1975.

Crawford, M. A., Doyle, W. \& Meadows, N. (1987), Gender Differences at Birth and Differences in Fetal Growth. Human Reproduction, 2 (6): 517-520.

Cromwell, J. B., Labys, W. C. \& Terraza, M. (1994), Univariate Tests for Time Series Models, Sage University Paper Series on Quantitative Applications in Social Sciences, 07-099. Thousand Oaks, CA: Sage. 
DRUŠ. ISTRAŽ. ZAGREB GOD. 20 (2011), BR. 1 (111) STR. $151-165$

PAVIĆ, D.: AN ANALYSIS OF SEX..
Fukuda, M., Fukuda, K., Shimizu, T. \& Moller, H. (1998), Decline in Sex Ratio at Birth after Kobe Earthquake. Human Reproduction, 13 (8): 2321-2322.

Gaulin, S. J. \& Robbins, C. J. (1991), Trivers-Willard Effect in Contemporary North American Society. American Journal of Physical Anthropology, 85 (1): 61-69.

Gelo, J. (1999), Ratni učinci na promjene demografskih struktura u Hrvatskoj. Društvena istraživanja, 8 (5-6): 735-749.

Graffelman, J. \& Hoekstra, R. F. (2000), A Statistical Analysis of the Effect of Warfare on the Human Secondary Sex Ratio. Human Bio$\log y, 72$ (3): 433-445.

Grant, V. J. (1996), Sex Determination and the Maternal Dominance Hypothesis. Human Reproduction, 11 (11): 2371-2375.

Gray, R. H., Simpson, J. L., Bitto, A. C., Queenan, J. T., Li, C., Kambic, R. T., Perez, A., Mena, P., Barbato, M., Stevensom, W. \& Jennings, V. (1998), Sex Ratio Associated with Timing of Insemination and Length of the Follicular Phase in Planned and Unplanned Pregnancies during Use of Natural Family Planning. Human Reproduction, 13 (5): 1397-1400.

Jacobsen, R. (2001), Parental Ages and the Secondary Sex Ratio. Human Reproduction, 16 (10): 2244.

Jacobsen, R., Moller, H. \& Engholm, G. (1999), Fertility Rates in Denmark in Relation to the Sexes of Preceding Children in the Family. Human Reproduction, 14 (4): 1127-1130.

James, W. H. (1971a), Coital Rate, Sex Ratio, and Parental Age. Lancet, 1 (7712): 1294.

James, W. H. (1971b), Coital Rate, Sex Ratio, and Season of Birth. Lancet, 2 (7716): 159.

James, W. H. (1987), The Human Sex Ratio. Part 1: A Review of the Literature. Human Biology, 59 (5): 721-752.

James, W. H. (1995), What Stabilizes the Sex Ratio? Annals of Human Genetics, 59 (Pt2): 243-249.

James, W. H. (1997), Sex Ratio, Coital Rate, Hormones and Time of Fertilization within the Cycle. Annals of Human Biology, 24 (5): 403-409.

James, W. H. (2000), Secular Movements in Sex Ratios of Adults and of Births during the Past Half-Century. Human Reproduction, 15 (5): 1178-1183.

James, W. H. (2001a), Variation in the Human Sex Ratio at Birth with Maternal Age, Parity and Placental Pathology. Human Reproduction, 16 (10): 2246-2247.

James, W. H. (2001b), Offspring Sex Ratios and the Causes of Placental Pathology: The Case of Placental Abruption. Human Reproduction, 16 (9): 2031

James, W. H. (2003a), Sex Ratios of Births Conceived during Wartime. Human Reproduction, 18 (5): 1133-1134.

James, W. H. (2003b), Sex Ratio at Birth and Exposure to Petrochemicals. Occupational \& Environmental Medicine, 60 (9): 704. 
DRUŠ. ISTRAŽ. ZAGREB GOD. 20 (2011), BR. $1(111)$

STR. 151-165

PAVIĆ, D.: AN ANALYSIS OF SEX...
James, W. H. (2004a), A Further Note on the Sex Ratios of Births Conceived during Wartime. Human Reproduction, 19 (6): 1495; author reply 1-6.

James, W. H. (2004b), Further Evidence that Mammalian Sex Ratios at Birth Are Partially Controlled by Parental Hormone Levels Around the Time of Conception. Human Reproduction, 19 (6): 1250-1256.

James, W. H. (2004c), 'Over-Ripeness Ovopathy, Sex Ratio Increase and Sex Ratio Reversal a Challenging Hypothesis for Sex Ratio Modulation': An Alternative Interpretation. Human Reproduction, 19 (4): 775-777.

James, W. H. (2005a), Offspring Sex Ratios of People Exposed to Electromagnetic Fields. Journal of Epidemiology \& Community Health, 59 (9): 810; author reply 81-1.

James, W. H. (2005b), The Sex Ratio of Offspring of Male Gasoline Filling Station Workers. Journal of Epidemiology \& Community Health 59 (4): 339.

James, W. H. (2006), The Sex Ratios of Offspring of Diabetic Parents. Diabetic Medicine, 23 (9): 1043-1044.

James, W. H. (2007), The Sex Ratio of Offspring of Patients with Systemic Lupus Erythematosus. Lupus, 16 (1): 65-66.

Jongbloet, P. H. (2004), Over-Ripeness Ovopathy: A Challenging Hypothesis for Sex Ratio Modulation. Human Reproduction, 19 (4): 769-774.

Lee Davis, D., Webster, P., Stainthorpe, H., Chilton, J., Jones, L. \& Doi, R. (2007), Declines in Sex Ratio at Birth and Fetal Deaths in Japan, and in U.S. Whites but Not African Americans. Environmental Health Perspectives, 115 (6): 941-946.

Maconochie, N. \& Roman, E. (1997), Sex Ratios: Are There Natural Variations within The Human Population? British Journal of Obstetrics and Gynaecology, 104 (9): 1050-1053.

Marcus, M., Kiely, J., Xu, F., McGeehin, M., Jackson, R. \& Sinks, T. (1998), Changing Sex Ratio in the United States, 1969-1995. Fertility and Sterility, 70 (2): 270-273.

Martin, J. F. (1997), Length of the Follicular Phase, Time of Insemination, Coital Rate and the Sex of Offspring. Human Reproduction, 12 (3): 611-616.

Mathews, F., Johnson, P. J. \& Neil, A. (2008), You Are What Your Mother Eats: Evidence for Maternal Preconception Diet Influencing Foetal Sex in Humans. Proceedings of the Royal Society, B 275 (1643): 1661-1668.

Mathews, T. J. \& Hamilton, B. E. (2005), Trend Analysis of the Sex Ratio at Birth in the United States. National Vital Statistics Reports, 53 (20): 1-17.

Mills, J. L., England, L., Granath, F. \& Cnattingius, S. (2003), Cigarette Smoking and the Male-Female Sex Ratio. Fertility and Sterility, 79 (5): 1243-1245.

Mrđen, S. i Friganović, M. (1998), The Demographic Situation in Croatia. Geoadria, 3 (1): 29-56. 
DRUŠ. ISTRAŽ. ZAGREB GOD. $20(2011)$, BR. $1(111)$ STR. $151-165$

PAVIĆ, D.: AN ANALYSIS OF SEX...
Nicolich, M. R., Huebner, W. W. \& Schnatter, A. R. (2000), Influence of Parental and Biological Factors on the Male Birth Fraction in the United States: An Analysis of Birth Certificate Data from 1964 through 1988. Fertility and Sterility, 73 (3): 487-492.

Parazzini, F., La Vecchia, C., Levi, F. \& Franceschi, S. (1998), Trends in Male: Female Ratio Among Newborn Infants in 29 Countries from Five Continents. Human Reproduction, 13 (5): 1394-1396.

Pokos, N. (2007), Promjene spolne strukture stanovništva Hrvatske 1953.-2001. godine. In: Lj. Bajs et al. (eds.), 4. hrvatski geografski kongres s medunarodnim sudjelovanjem: geografsko vrednovanje prostornih resursa (proceedings), (pp. 207-219), Zagreb, Hrvatsko geografsko društvo.

Polasek, O. (2006), Did the 1991-1995 Wars in the Former Yugoslavia Affect Sex Ratio at Birth? European Journal of Epidemiology, 21 (1): 61-64.

Polasek, O., Kolcic, I., Kolaric, B. \& Rudan, I. (2005), Sex Ratio at Birth and War in Croatia (1991-1995). Human Reproduction, 20 (9): 2489-2491.

Ruder, A. (1985), Paternal-Age and Birth-Order Effect on the Human Secondary Sex Ratio. American Journal of Human Genetics, 37 (2): 362-372.

Saadat, M. \& Ansari-Lari, M. (2004), Sex Ratio of Birth during Wartime and Psychological Tensions. Human Reproduction, 19 (2): 465.

Teitelbaum, M. (1971), Male and Female Components of Perinatal Mortality: International Trends 1901-63. Demography, 8 (4): 541-548.

Teitelbaum, M. (1972), Factors Associated with the Sex Ratio in Human Populations. In: G. A. Harrison \& A. J. Boyce (eds.), The Structure of Human Populations (pp. 90-109), Oxford, England: Clarendon Press.

Trivers, R. L. \& Willard, D. E. (1973), Natural Selection of Parental Ability to Vary the Sex Ratio of Offspring. Science, 179 (68): 90-92.

Ulizzi, L. \& Zonta, L. A. (1994), Sex Ratio and Selection by Early Mortality in Humans: Fifty-Year Analysis in Different Ethnic Groups. Human Biology, 66 (6): 1037-1048.

Ulizzi, L. \& Zonta, L. A. (1995), Factors Affecting the Sex Ratio in Humans: Multivariate Analysis of the Italian Population. Human Bio$\log y, 67$ (1): 59-67.

Vartiainen, T., Kartovaara, L. \& Tuomisto, J. (1999), Environmental Chemicals and Changes in Sex Ratio: Analysis Over 250 Years in Finland. Environmental Health Perspectives, 107 (10): 813-815.

Zorn, B., Sucur, V., Stare, J. \& Meden-Vrtovec, H. (2002), Decline in Sex Ratio at Birth after 10-Day War in Slovenia: Brief Communication. Human Reproduction, 17 (12): 3173-3177.

Živić, D. (1999), Promjene u dinamici i razmještaju prognaničko-izbjegličkog kontingenta u Republici Hrvatskoj od sredine 1991. do sredine 1998. godine (Changes in the Dynamics and Distribution of the Displaced-Refugee Contingent in Croatia from mid 1991 to mid 1998). Društvena istraživanja, 8 (5-6): 767-791. 
DRUŠ. ISTRAŽ. ZAGREB GOD. 20 (2011), BR. $1(111)$

STR. 151-165

PAVIĆ, D.: AN ANALYSIS OF SEX..

\section{Analiza omjera spolova novorođenčadi u Hrvatskoj od 1946. do 2007.}

\section{Dario PAVIĆ}

Hrvatski studiii, Zagreb

Omjer spolova novorođenčadi jest demografska kategorija koju se ponajviše istraživalo, no koju se još nedovoljno razumije. Čini se da mnogi fiziološki, ekološki i demografski čimbenici utječu na taj omjer, iako nema jednoznačnog objašnjenja ovoga fenomena. Isto tako, mnoge zemlje iskazuju postojanje trenda kod omjera spolova novorođenčadi tijekom godina, a ta se serija može modelirati kao nenasumični stohastički proces koji odražava međuovisnost pojedinih godišnjih opservacija. Ovaj članak istražuje omjer spolova novorođenčadi u Republici Hrvatskoj od 1946. do 2007. godine. Proveli smo testove za utvrdivanje tipa vremenske serije, kao i autoregresijski model. Vremenska serija omjera spolova novorođenčadi u Republici Hrvatskoj proizvod je čistoga nasumičnog procesa bez utvrđenoga trenda, iako su prisutni neki od čimbenika koji utječu na taj omjer. Cini se da veličina populacije živorođenih nije dovolino velika da bi odražavala suptilne promjene u navedenim čimbenicima.

Ključne riječi: omjer spolova novorođenčadi, Hrvatska, analiza vremenskih serija, autoregresija

\section{Eine Analyse zur Geschlechterverteilung unter den Neugeborenen in Kroatien von 1946 bis 2007}

Dario PAVIĆ

Kroatische Studien, Zagreb

Die Geschlechterverteilung unter Neugeborenen gehört zu den am meisten untersuchten, aber immer noch unzureichend verstandenen Kategorien. Offensichtlich wird das Zahlenverhältnis zwischen Mädchen und Jungen durch viele physiologische, umweltbedingte und demografische Faktoren beeinflusst; eine eindeutige Erklärung des Phänomens gibt es jedoch nicht. Ebenso bestätigen viele Länder das Bestehen eines gewissen Trends in der Geschlechterverteilung, der sich über mehrere Jahre halten kann. Eine solche Geburtenserie kann sich als nicht zufälliger stochastischer Prozess ausprägen, der die Wechselwirkung zwischen einzelnen Jahresbeobachtungen reflektiert. In diesem Artikel wird die Geschlechterverteilung unter Neugeborenen in Kroatien zwischen 1946 und 2007 untersucht. Angewandt wurden Tests zur Ermittlung jeweiliger zeitlicher Geburtenserien sowie ein Autoregressionsmodell. 
DRUŠ. ISTRAŽ. ZAGREB GOD. 20 (2011), BR. 1 (111)

STR. 151-165

PAVIĆ, D.

AN ANALYSIS OF SEX..
Eine ermittelte zeitliche Geburtenserie mit Daten zur Geschlechterverteilung ist das Ergebnis eines reinen Zufallsprozesses ohne ermittelten Trend, trotz bestimmter bestehender Faktoren, die das Zahlenverhältnis zwischen männlichen und weiblichen Neugeburten beeinflussen können. Es entsteht der Eindruck, dass der Geburtenzuwachs nicht umfangreich genug ist, um subtile Veränderungen in den genannten Faktoren sichtbar zu machen.

Schlüsselbegriffe: Geschlechterverteilung unter Neugeborenen, Kroatien, Analyse bestimmter zeitlicher Geburtenserien, Autoregression 